\title{
Blood-based biomarkers in Alzheimer's disease: an overview on proteomic and lipidomic approaches
}

\section{Biomarkeri sanguini în boala Alzheimer: abordări proteomice și lipidomice}

\author{
Geanina Andreea Ilinoiu ${ }^{1,2,3}$, Raluca Tirintica ${ }^{1}$, Cosmin $_{\text {Lungu }}{ }^{4}$, Adriana Mihai ${ }^{1,5, *}$ \\ ${ }^{1}$ University of Medicine and Pharmacy Tîrgu Mureş, România, Psychiatry Department; \\ ${ }^{2}$ Central Military Hospital ,,Dr Carol Davila”, Bucharest, Romania, Psychiatry Department; \\ ${ }^{3}$ Department of Adult Mental Health Inpatient, Lanchester Road Hospital, Durham, United Kingdom; \\ ${ }^{4}$ Sociology and Psychiatry Faculty, ,, Spiru Haret” University, Bucharest, Romania; \\ ${ }^{5}$ Psyhotherapy and Personal Development Institute, Tîrgu Mureş, Romania.
}

\begin{abstract}
Alzheimer's disease (AD) remains one of the most challenging pathologies since its etiology is not completely known, its progression is slow and there are no disease-changing pharmacological agents available yet. One other important characteristic is that the progression of AD pathology starts long before any symptoms are experienced by patients. This is where the need for early detection biomarkers comes from. Although there are biomarkers that have been intensely studied and are now included in research criteria, most of these biomarkers are either invasive or unaffordable. Blood-based biomarkers could be a viable alternative of accessible and acceptable biomarkers, and have been much studied in the past decade. Among them proteomics and lipidomics seem to be two most promising fields for biomarker development. The paper aims to offer an overview of developments in the field during the past 5 years highlighting the most promising biomarkers.
\end{abstract}

Keywords: blood biomarkers, Alzheimer's disease, proteomics, lipidomics.

\section{Rezumat}

Boala Alzheimer (BA) ramâne una dintre cele mai intrigante patologii neurocognitive deoarece etiologia ei nu este complet elucidate, progresia ei este lentă şi nu există terapii care să modifice cursul bolii la momentul actual. $O$ altă caracteristică importanta este aceea că debutul BA are loc cu mult înainte ca primele simptome să fie resimţite de către pacient. Aici intervine nevoia de biomarkeri de detecţie precoce. Cu toate că există markeri biologici care au fost intens cercetaţi şi care acum sunt incluşi în criteriile de cercetare, cei mai mulţi dintre aceştia sunt fie invazivi, fie prea costisitori. Biomarkerii sanguini ar a fi o alternativă viabilă de biomarkeri accesibili și acceptabili, şi au fost studiaţi intens în ultima decadă. In această categorie domeniile proteomicii şi lipidomicii sunt cele mai promiţătoare. Lucrarea de faţă are ca scop prezentarea unei imagini de ansamblu a rezultatelor obţinute în acest domeniu în ultimii 5 ani cu accent pe acei biomarkeri care au avut rezultatele cele mai încurajatoare.

Cuvinte cheie: biomarkeri sanguini, boala Alzheimer, proteomica, lipidomica.

Received: $16^{\text {th }}$ November 2015; Accepted: $26^{\text {th }}$ March 2016; Published: $28^{\text {th }}$ April 2016.

* Corresponding author: Adriana Mihai, University of Medicine and Pharmacy Tg Mures, Psychiatry, Gh Marinescu 38, Tg Mures, Romania, e-mail: dradrianamihai@yahoo.com 


\section{Introduction}

It is now a well-known fact that Alzheimer's (AD) disease is the most common cause of dementia worldwide. A report of the Alzheimer's Association shows that AD accounts for approximately 60 to $80 \%$ of the cases and about half of these cases involve only AD pathology (1). In 2012 the World Health Organization (WHO) estimated that there were about 35.6 million people living with dementia and predicted that the number will double by 2030 as a result of an aging population (2). In the European Union reports show an average of $1.55 \%$ (3) of the population diagnosed with $\mathrm{AD}$ as compared to $11 \%$ in the USA (1). It would seem that the situation is better in Europe, but the small percentage of diagnosed patients may only represent a higher number of undiagnosed ones on which no data is available.

$\mathrm{AD}$ represents one of the most challenging pathologies among other fast growing world- wide epidemics because its etiology is still uncertain, its progression is slow and the first clinical symptoms appear long after the pathological processes have begun (4).

Decades of $\mathrm{AD}$ research bring some light over the underlying pathophysiology of this disease: amyloid $\beta(\mathrm{A} \beta)$ plaques and neurofibrillary tangles (NFTs). AD drug development failed to come up with potentially disease-modifying therapies so far (5), but there are still ongoing Phase II and III trials that seem encouraging $(6,7)$ (Figure 1).

\section{Biomarkers - old and new}

While waiting for efficient AD therapies, biological markers (biomarkers) are growing in significance since they appear to be able to reveal underlying disease processes and thus ensure an earlier intervention on disease progression.

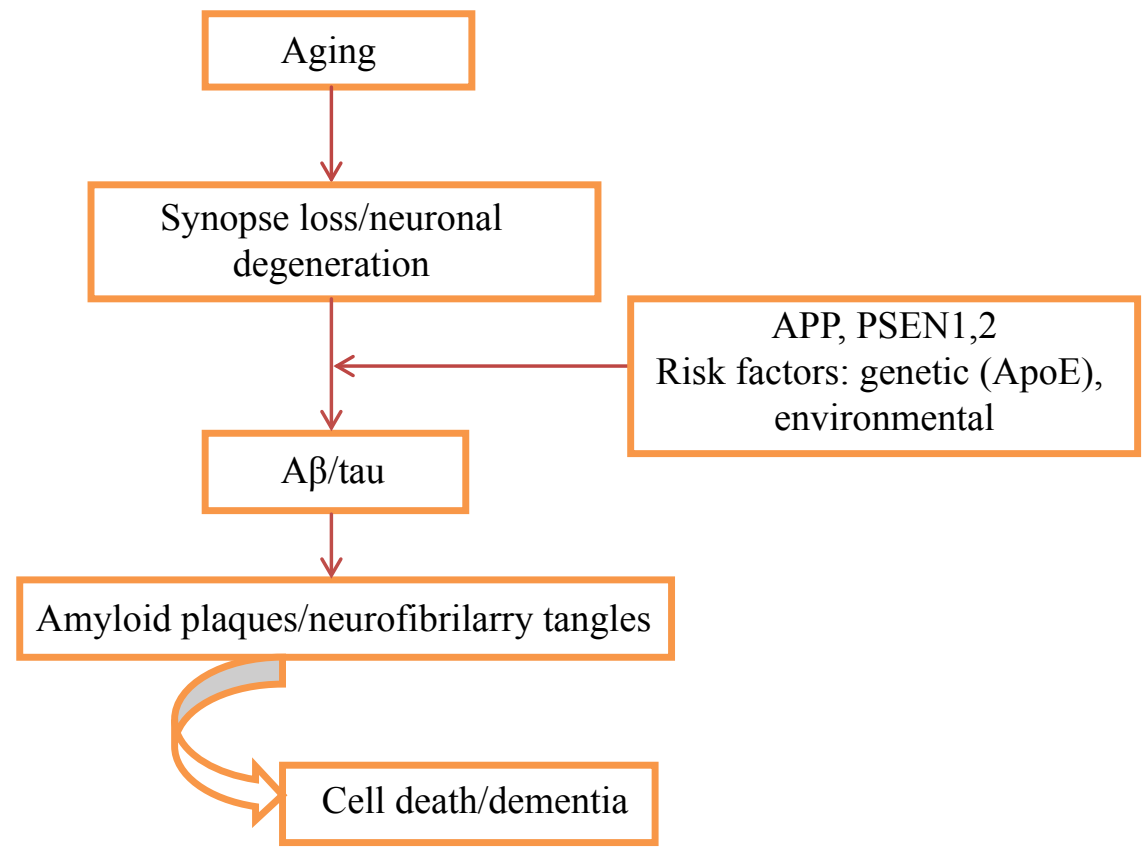

Figure 1. Amyloid cascade hypothesis

APP - amyloid beta precursor protein; PSEN1,2 - presenilin genes; ApoE - apolipoprotein E; A $\beta$ - amyloid beta. 
A biomarker represents "an objective indicator of normal biological processes, pathogenic processes, or pharmacologic responses to a therapeutic intervention" (8). Up to the present day there are at least six investigation procedures (biochemical measurements or scanning procedures) used as biomarkers in detecting AD and included in the most recent research criteria (9). There are three imaging biomarkers - namely hippocampal atrophy (evaluated by structural magnetic resonance imaging - MRI), decreased uptake of a radiotracer called [18F]-2-fluoro2-deoxy-D-glucose (FDG) in certain regions on positron emission tomography (FDG-PET) and an increased retention of an amyloid tracer (PIB-PET). The other three biomarkers are cerebrospinal fluid (CSF) biomarkers: low levels of $\mathrm{A} \beta 42$, elevated levels of total tau proteins ( $\mathrm{t}$-tau) and phosphorilated tau (p-tau).

Along these biomarkers that are included in the diagnostic and research criteria there are also genetic biomarkers: mutations in certain genes - amyloid precursor protein (APP) genes, presenilin genes (PSEN1 and PSEN2); $\varepsilon 4$ apolipoprotein $\mathrm{E}$ (APOE) phenotype $(10,11)$.
One set of biomarkers that have been regarded as an effective way to boost the utility of both CSF and imaging biomarkers are the blood based biomarkers. Their analysis represents the first step in a complex process of screening and diagnostic (12). Blood based biomarkers are both time and cost efficient, non-invasive and a good source for repeated measurements. Given that not many people are keen to undergo a lumbar puncture (LP) procedure for CSF sampling, the development of a reliable blood biomarker appears to be a valuable tool worth researching.

The aim of this review is to present the most recent developments in both old and novel blood based biomarkers focusing on two main domains: proteomics and lipidomics. We searched PubMed database using the following words: "blood biomarkers", "Alzheimer's disease", "proteomics", "lipidomics". Out of a total number of 2058 articles, we included only clinical trials, published in the last 5 years. We excluded review articles and meta-analysis articles. There were a total number of 24 research articles that fit the inclusion criteria and were included in the review analysis (Figure 2).

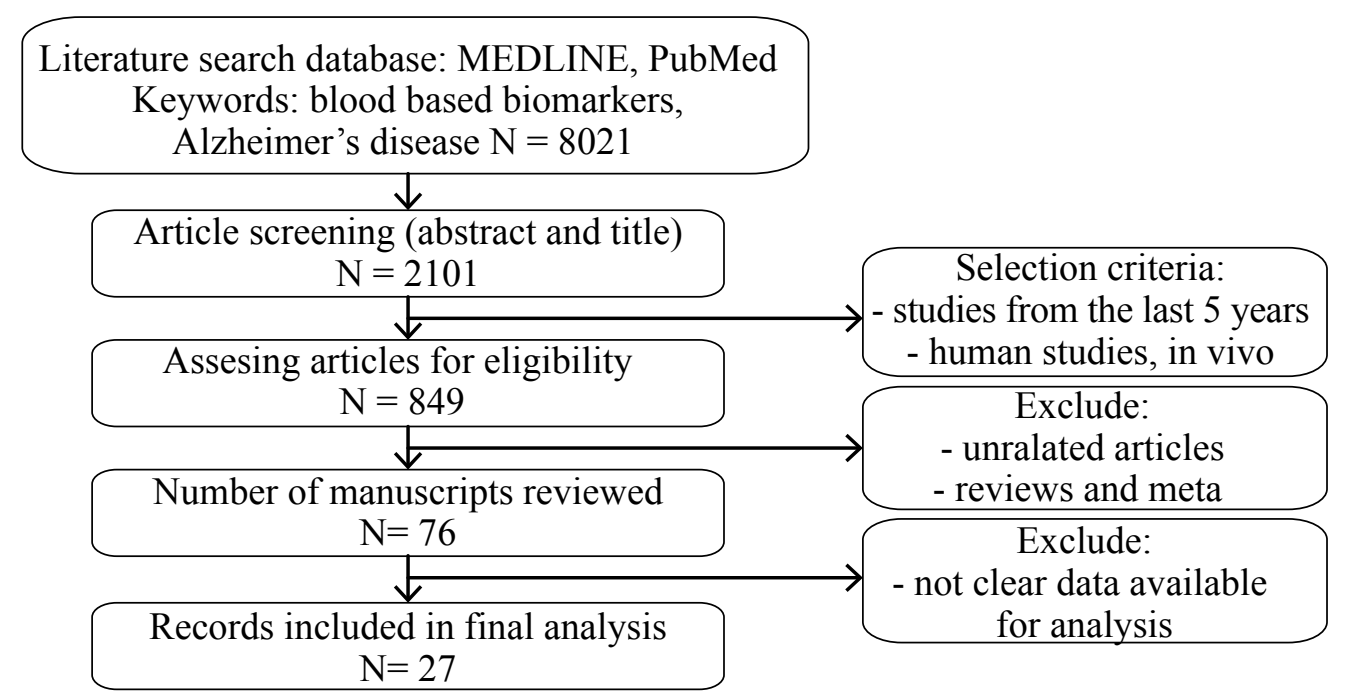

Figure 2. Diagram flow of the literature search process 
A summary of analyzed records and the level of correlation with AD pathology of certain potential biomarkers is shown in Table 1.

\section{Proteomics}

A brain-related pathology is more likely to be reflected in brain proteins. However, the blood-

Table 1. Analyzed studies about blood based biomarkers, level of correlation of the biomarker with AD pathology and the use early detection

\begin{tabular}{llcc}
\hline BLOOD BASES BIOMARKERS & $\begin{array}{l}\text { Article included } \\
\text { (Year of publication) }\end{array}$ & $\begin{array}{l}\text { Level of } \\
\text { corelation }\end{array}$ & $\begin{array}{l}\text { Use for } \\
\text { early } \\
\text { detection }\end{array}$ \\
\hline Proteomic approaches & & & \\
\hline ApoE plasma levels & Teng E et al. $(2015)[13]$ & + & + \\
\cline { 2 - 4 } & Gupta et al. $(2011)[14]$ & + & + \\
\hline A1M, ApoE, BNP, IL16, SGOT & Guo LH et al.(2013) [16] & + & + \\
\hline NT proBNP & Marksteiner J et al. $(2014)[17]$ & + & + \\
\hline ApoE, BNP, CRP, pancreatic polypeptide & Hu WT et al.(2012) $[18]$ & + & + \\
\hline Cortisol, pancreatic polypeptide, IGFBP2, & Doecke JD et al.(2012) [19] & + & \pm
\end{tabular}

homocysteine/ ApoE, epidermal growth

factor, hemoglobin, IL17, albumin

\begin{tabular}{|c|c|c|c|}
\hline EGF, PDG-BB and MIP-1 $\delta$ & Bjorkgvist M et al. (2012)[20] & + & \pm \\
\hline IGF II and IGF BP2 & Hertze et al. (2014) [22] & & \\
\hline \multirow[t]{7}{*}{ Amyloid-beta } & Sotolongo-Grau O et al. (2014) [23] & + & + \\
\hline & Lewczuk P et al. (2010) [24] & + & + \\
\hline & Lui JK et al. (2010) [25] & \pm & \pm \\
\hline & Cosentino SA et al. (2010) [26] & + & + \\
\hline & Laske C et al. (2010) [27] & + & + \\
\hline & Yaffe K et al. (2011) [28] & + & ++ \\
\hline & Wu G et al. (2012) [31] & \pm & \pm \\
\hline \multirow[t]{2}{*}{ Tau proteins } & Noguchi-Shinohara M et al. (2011)[32] & - & - \\
\hline & Zetterberg H et al. (2013) [33] & - & - \\
\hline \multicolumn{4}{|l|}{ Lipidomic approaches } \\
\hline Fatty acids, C26:0 & Zarrouk A et al. (2015) [36] & \pm & $?$ \\
\hline Ceramids, sphingomyelins & Han X et al. (2011) [37] & + & + \\
\hline Sphingomyelin/ceramide ratio & Mielke MM et al. (2011) [38] & - & - \\
\hline \multirow[t]{2}{*}{ DHA, omega 3 fatty acids } & Jerneren F et al. (2015) [39] & + & - \\
\hline & Baierle M et al. (2014) [40] & + & - \\
\hline EPA, DHA, omega 3 fatty acids & Freund Levi Y et al. (2014) [41] & + & + \\
\hline 10 lipid panel & Mapstone M et al. (2014) [42] & + & + \\
\hline
\end{tabular}

+ - positive correlation/use in early detection; \pm - uncertain correlation/use in early detection;

- - no correlation/use in early detection; ? - no data available. 
brain barrier (BBB) stands between the peripheral blood circulation and the brain, protecting it from harmful substances in the blood and it doesn't seem to be particularly affected by AD pathology (13). Still, a small quantity of brain proteins are absorbed from the CSF into the bloodstream and this is how their detection in plasma is possible.

\section{Plasma Apolipoprotein E (ApoE) Levels}

While the correlation between ApoE genotype and $\mathrm{AD}$ has been strongly demonstrated over the time, there are still uncertainties related to the use of ApoE plasma levels. The link between plasma ApoE levels and the hippocampal volume was recently assessed is a study (14). Lower plasma levels of ApoE turned out to correlate significantly with a smaller hippocampal size. There have also been prior reports that lower ApoE plasma levels correlate with a greater cortical retention of Pittsburgh Compound B (PIB). These findings reveal that plasma ApoE levels might be considered as a peripheral marker for AD pathology in early stages of the disease, especially in carriers of ApoE $\varepsilon 4$ allele. What is more, altered ApoE plasma levels also seem to be correlated with the advancement of the pathology (15).

\section{Other proteomic approaches}

A German study from 2013 analyzed seven plasma proteins and compared their levels between control and $\mathrm{AD}$ groups. The assessed plasma proteins were: alpha-1-microglobulin (A1M), apolipoprotein E (ApoE), brain natriuretic peptide (BNP), betacellulin (BTC), eotaxin-3, interleukin-16 (IL16) and serum glutamic oxaloacetic transaminase (SGOT). Five of the seven proteins appeared to be involved in AD pathology (A1M, ApoE, BNP, IL16 and SGOT), but over a 5 year follow-up of a population with MCI, only ApoE resulted in significant lower concentrations (16).

An analysis of 27 proteins in the peripheral blood led to the conclusion that among them, the N-terminal pro-brain natriuretic peptide (NT-proBNP) could be a viable candidate for a biomarker of both diagnosis and progression in AD (17). The Gene/Environment Susceptibility (AGES)-Reykjavik Study analysed measured the NT-proBNP serum levels in over 4000 elderly individuals. Results show that high levels of serum NT-proBNP are independently linked with structural and functional alterations of the brain (18).

Another study made on two large cohorts with normal cognition and cognitive impairment identified ApoE, BNP, C-reactive protein (CRP) and pancreatic polypeptide levels to be associated with MCI or AD diagnosis and correlated with $\mathrm{CSF}$ biomarker profiles for AD (19). However, the researchers admit the limitations of the study given by alterations of these analytes in shared pathologies (vascular disease, acute stroke). But assessed routinely for screening purposes and correlated with CSF biomarkers they appear to be a useful tool.

A community-based, prospective, longitudinal study of aging identified a biomarker panel which included markers that were increased significantly (such as cortisol, pancreatic polypeptide, insulin growth factor binding protein 2 , carcinoembryonic antigen, homocysteine and others) or decreased (ApoE, epidermal growth factor, hemoglobin, IL17, albumin) in AD patients (20). Researchers have tried to reproduce the analysis of different plasma protein panels (21) starting from the first panel ever proposed in 2007 by Ray et al. (22) with promising results.

Insulin-like Growth Factor (IGF) is known to be involved in neurodegeneration and cell repair. A study performed on $\mathrm{AD}$ and healthy controls 
found significantly lower plasma levels of IGFII and IGF binding protein 2 in AD patients as compared with controls, while being significantly increased in the CSF of the same patients (23).

\section{Serum amyloid $\beta$ (A $\beta)$}

In a recent study conducted by Sotolongo-Grau et al. (24) an association between certain $A \beta$ fractions and the hippocampal volume were found. The study shows correlations between cell-bound blood $\mathrm{A} \beta$ 1-40 levels and alterations in the left hippocampus, an important site for the AD pathology.

Research projects that studied AD and mild cognitive impairment of AD type (MCI-AD) patients show that they had significantly lower $A \beta 1-42$ plasma concentrations and lower $A \beta 1$ 42/1-40 ratios as compared to patients with other types of MCI or dementias (25-27). What is more there have been found correlations between $A \beta$ plasma levels and the rate of cognitive decline independent of baseline psychological scores, age or treatment intake, but dependent on history of stroke and myocardial infarction (28).

An interesting development in the field of $A \beta$ plasma levels is brought by a study that shows lower levels of $A \beta 42 / 40$ being associated with a greater cognitive decline in elderly without dementia over a follow-up period of 9 years (29).

It is worth mentioning that there have been conflictual opinions on the implications of $A \beta$ levels in AD pathology over time. Some studies have shown an increased risk of $\mathrm{AD}$ with increased $A \beta 40$ and $A \beta 42(30,31)$ while others reported a higher risk with decreased levels of $A \beta$. As shown before, the data from the last five years seem to agree on an increased risk when A $\beta$ plasma levels are decreased.

Interestingly, plasma $\beta$-site amyloid precursor proteins (APP) cleaving enzyme activity (BACE1) and soluble APP proteins were found elevated in the plasma of AD patients (32). This finding is of potential pharmacodynamical importance in the study of secretase inhibitors.

\section{Tau proteins in plasma}

Serum tau does not appear to accurately reflect the level of CSF tau as shown in multiple studies $(33,34)$. Transient increases in plasma tau levels may appear as a result of ischemic stroke, hypoxic or traumatic brain injury $(35,36)$ and thus interfere with an accurate measurement in $\mathrm{AD}$ pathology. Zetterberg and colleagues (34) have shown a relative overlap between measurements in patients with $\mathrm{AD}, \mathrm{MCI}$ and normal controls, and progression to $\mathrm{AD}$ of $\mathrm{MCI}$ patients could not be determined.

\section{Autolysosomal proteins}

Preliminary results of a study expanding over more than 10 years which measured different autolysosomal proteins in neutrally derived blood exosomes in $\mathrm{AD}$ patients compared to healthy controls are at least intriguing. The investigation is meant to point out abnormal neuronal autophagy and the production of several proteins such as lysosome-associated membrane protein 1 (LAMP-1) and ubiquitinylated proteins. Levels of autolysosomal proteins turned out to be higher in AD patients as compared to controls and seemed to be present up to 10 years before the clinical onset of the disease (37).

\section{Lipidomics}

Several lipid metabolism alterations have been found in the brain and in the plasma of AD patients. Zarrouk and colleagues (38) found significant alterations of fatty acid levels in patients with $\mathrm{AD}$ and a significant accumulation of hexacosanoic acid (C26:0) in plasma. 
Also alterations in ceramides and sphingomyelins have been considered to be involved in amyloid genesis and neuronal apoptosis. In light of this knowledge Han and colleagues (39) analyzed over 800 molecular species of lipids in AD and cognitively normal individuals. They observed a disruption in sphingomyelin and ceramide mass plasma levels in AD patients, observation which may be used in future to develop the potential of metabolomics as plasma biomarkers. Even though the observations seem promising, another study showed that an increased ratio of sphingomyelin/ ceramide might predict a slower progression of the disease in demented patients (40).

Data from some research projects $(41,42)$ show that low levels of docosahexanoic acid (DHA) and low levels of omega-3 fatty acids in plasma may represent a risk factor for cognitive impairment. It has recently been shown that dietary supplementation with omega-3 fatty acids can lead to a significant increase in CSF and plasma eicosapentanoic acid (EPA), DHA and total omega-3 fatty acids in patients with AD suggesting the possibility of their transition through the blood-brain barrier (43).

A more recent study showed some controversial and intriguing results describing a panel of 10 lipids from the peripheral blood reflecting cell membrane integrity that predict conversion to $\mathrm{AD}$ within 2-3 years with an accuracy of 90\% (44).

As a whole, lipidomics has clearly shown that two important structural lipid classes are decreased in patients with AD: glycerophospholipids and sphingolipids, but the importance of these deficits for the pathophysiology of AD still remains under discussion.

\section{Conclusions}

In summary, blood-based biomarkers appear to be fairly accessible for researchers and acceptable to patients.
The most promising class of biomarkers seems to be the development of proteomics. With future development of biotechnology there will be greater capacity to assess and investigate a higher number of datasets in order to better identify, stage and maybe even treat AD.

Lipidomics shows great potential as AD biomarker. However, much work needs to be performed in order to understand lipid dysregulation in $\mathrm{AD}$ and eventually identify novel therapeutic agents.

Identifying novel blood-based biomarkers for early detection should represent a priority since early interventions could slow down progression and provide the patients a longer time of independence.

\section{Acknowledgements}

The first author received a grant from European Social Found, Human Resources Development Operational Program 2007-2013, project no. POSDRU/159/1.5/S/136893.

\section{List of abbreviations}

$\begin{array}{ll}\text { A } \beta & \text { - amyloid beta } \\ \text { A1M } & \text { - alpha-1-microglobulin } \\ \text { AD } & \text { - Alzheimer's disease } \\ \text { APOE } & \text { - apolipoprotein E } \\ \text { APP } & \text { - amyloid precursor protein } \\ \text { BACE 1 } & \text { - beta-amyloid precursor protein } \\ & \text { cleaving enzyme } \\ \text { BBB } & \text { - blood-brain barrier } \\ \text { BNP } & \text { - brain natriuretic peptide } \\ \text { BTC } & \text { - betacellulin } \\ \text { CRP } & \text { - C-reactive protein } \\ \text { CSF } & \text { - cerebrospinal fluid } \\ \text { DHA } & \text { - docosahexanoic acid } \\ \text { EPA } & \text { - eicosapentanoic acid }\end{array}$




\begin{tabular}{|c|c|}
\hline FDG-PET & $\begin{array}{l}\text { - fluorodeoxyglucose - positron } \\
\text { emission tomography }\end{array}$ \\
\hline IGF & - insulin-like growth factor \\
\hline IGF-BP2 & $\begin{array}{l}\text { - insulin-like growth factor - } \\
\text { binding protein } 2\end{array}$ \\
\hline IL16 & - interleukin 16 \\
\hline MRI & - magnetic resonance imaging \\
\hline $\begin{array}{l}\text { NINCSD- } \\
\text { ADRDA }\end{array}$ & $\begin{array}{l}\text { - National Institute of Neurolog- } \\
\text { ical and Communicative Disor- } \\
\text { ders and Stroke - Alzheimer's } \\
\text { Disease and Related Disorders } \\
\text { Association }\end{array}$ \\
\hline NFTs & - neurofibrillary tangles \\
\hline NT-proBNP & $\begin{array}{l}\text { - N-terminal pro-brain natriuretic } \\
\text { peptide }\end{array}$ \\
\hline PIB & - Pittsburg Compound B \\
\hline PSEN & - presenilin \\
\hline p-tau & - phosphorylated tau proteins \\
\hline$-\operatorname{tau}$ & - total tau proteins \\
\hline $\mathrm{jOT}$ & - serum oxaloacetic transaminase \\
\hline
\end{tabular}

\section{References:}

1. Alzheimer's Association. 2015 Alzheimer's disease facts and figures. Alzheimer's and Dementia 2015;11(3):332. DOI: 10.1016/j.jalz.2015.02.003.

2. Saloni Tanna, 2004 Background Paper 6.11. Alzheimer Disease and other Dementias. Last updated February 20, 2013. Available at http://www.who.int/medicines/ areas/priority_medicines/BP6_11Alzheimer.pdf.

3. Alzheimer Europe. The prevalence of Alzheimer in Europe. Available at: http://www.alzheimer-europe.org/Policyin-Practice2/Country-comparisons/The-prevalence-ofdementia-in-Europe. Last update: February 24, 2014.

4. Hampel H, Prvulovic D, Teipel S, Jessen F, Luckhaus C, Frolich L, et al. The future of Alzheimer's disease: the next 10 years. Prog Neurobiol. 2011 Dec; 95(4):71828. DOI: 10.1016/j.pneurobio.2011.11.008.

5. Karran E, Hardy J. A critique of the drug discovery and phase 3 clinical programs targeting the amyloid hypothesis for Alzheimer Disease. Ann Neurol. 2014 Aug; 76(2):185-205. DOI: 10.1002/ana.24188.
6. Rinne JO, Brooks DJ, Rossor MN, Fox NC, Bullock $\mathrm{R}$, Klunk WE, et al. 11C-PIB PET assessment of change in fibrillary amyloid-beta load in patients with Alzheimer's disease treated with bapineuzumab: a phase 2, double-blind, placebo-controlled, ascending-dose study. Lancet Neurol. 2010 Apr; 9(4):363-72. DOI: $10.1016 / \mathrm{S} 1474-4422(10) 70043-0$.

7. Karran E, Hardy J. Antiamyloid therapy for Alzheimer's disease - are we on the right road? N Engl J Med. 2014 Jan 23; 370(4):377-8. DOI: 10.1056/NEJMe1313943.

8. Bier JC. Biomarkers of Alzheimer's disease: concepts and clinical case. Rev Med Brux. 2013 Sep. 34(4):306-10.

9. McKhann GM, Knopman DS, Chertkow H, Hyman BT, Jack CR Jr, Kawas CH, et al. The diagnosis of dementia due to Alzheimer's disease: recommendations from the National Institute on Aging-Alzheimer's Association workgroups on diagnostic guidelines for Alzheimer's disease. Alzheimers Dement. 2011 May; 7(3):263-9. DOI: 10.1016/j.jalz.2011.03.005.

10. Kuwano R, Hara N. Personal genomics for Alzheimer's disease. Brain Nerve. 2013 65(3):235-46.

11. Ridge PG, Mukherjee S, Crane PK, Kauwe JS; Alzheimer's Disease Genetics Consortium. Alzheimer's disease: analyzing the missing heritability. PLoS One. 2013 Nov 7;8(11):e79771. DOI: 10.1371/journal. pone. 0079771 .

12. Henriksen K, O’Bryant SE, Hampel H, Trojanowski JQ, Montine TJ, Jeromin A, et al. The future of bloodbased biomarkers for Alzheimer's disease. Alzheimers Dement. 2014 Jan; 10(1):115-131. DOI: 10.1016/j. jalz.2013.01.013.

13. Chalbot S, Zetterberg H, Blennow K, Fadby $\mathrm{T}$, Andreasen N, Grundke-Igbal I, et al. Bloodcerebrospinal fluid barrier permeability in Alzheimer's disease. J Alzheimers Dis. 2011; 25(3):505-15.

14. Teng E, Chow N, Hwang KS, Thompson PM, Gylys $\mathrm{KH}$, Cole GM, et al. Low plasma ApoE levels are associated with smaller hippocampal size in the Alzheimer's disease neuroimaging initiative cohort. Dement Geriatr Cogn Disord. 2015; 39(3-4):154-66. DOI: $10.1159 / 000368982$.

15. Gupta VB, Laws SM, Villemagne VL, Ames D, Bush AI, Ellis KA, et al. Plasma apolipoprotein E and Alzheimer disease risk: the AIBL study of aging. Neurology. 2011 Mar 22; 76(12):1091-8. DOI: 10.1212/WNL.0b013e318211c352. 
16. Guo LH, Alexopoulos P, Wagenpfeil S, Kurz A, the Alzheimer's Disease Neuroimaging Inititative, Perneczcky R. Plasma proteomics for the identification of Alzheimer's disease. Alzheimer Dis Assoc Disord. 2013 Oct-Dec; 27(4):10. DOI: 10.1097/ WAD.0b013e31827b60d2.

17. Marksteiner J, Imarhiagbe D, Defrancesco M, Deisenhammer EA, Kemmler G, Humpel C. Analysis of 27 vascular related proteins reveals that NT-proBNP is a potenatial biomarker for Alzheimer's disease and mild cognitive impairment: a pilot-study. Exp Gerontol. 2014 Feb; 50:114-21. DOI: 10.1016/j.exger.2013.12.001.

18. Behnam S, A van Buchem M, JM de Craen A, Sigurdsson S, Zhang Q, Harris TB, et al. N-terminal pro-brain natriuretic peptide and abnormal brain aging. Neurology. 2015 Sept 1; 85(9):813-820. DOI: 10.1212/ WNL.0000000000001885.

19. Hu WT, Holtzman DM, Fagan AM, Shaw LM, Perrin $\mathrm{R}$, Arnold SE, et al. Plasma multyanalyte profiling in mild cognitive impairment and Alzheimer disease. Neurology. 2012 Aug 28; 79(9):897-905. DOI: 10.1212/WNL.0b013e318266fa70.

20. Doecke JD, Laws SM, Faux NG, Wilson W, Burnham SC, Lam CP, et al. Blood-based protein biomarkers for diagnosis of Alzheimer disease. Arch Neurol. 2012 Oct; 69(10):1318-25. DOI: 10.1001/archneurol.2012.1282.

21. Bjorkgvist M, Ohlsson M, Minthon L, Hansson O. Evaluation of a previously suggested plasma biomarker panel to identify Alzheimer's disease. PLoS One. 2012. 7(1): e29868. DOI: 10.1371/journal. pone.0029868.

22. Ray S, Britschgi M, Herbert C, Takeda-Uchimura Y, Boxer A, Blennow K, et al. Classification and prediction of clinical Alzheimer's diagnosis based on plasma signaling proteins. Nat Med. 2007 Nov; 13(11):135962. DOI: $10.1038 / \mathrm{nm} 1653$.

23. Hertze J, Nagga K, Minthon L, Hansson O. Changes in cerebrospinal fluid and blood plasma levels of IGFII and its binding proteins in Alzheimer's disease: an observational study. BMC Neurol. 2014 Apr 1; 14:64. DOI: 10.1186/1471-2377-14-64.

24. Sotolongo-Grau O, Pesini P, Valero S, Lafuente A, Buendia M, Perez-Grijalba V, et al. Association between cell-bound blood amyloid- $\beta(1-40)$ levels and hippocampus volume. Alzheimers Res Ther. 2014; 6(5):56. DOI: 10.1186/s13195-014-0056-3.
25. Lewczuk P, Kornhuber J, Vanmechelen E, Peters O, Heuser I, Maier W, et al. Amyloid beta peptides in plasma in early diagnosis of Alzheimer's disease: a multicenter study with multiplexing. Exp Neurol. 2010 Jun; 223(2):366-70. DOI: 10.1016/j.expneurol.2009.07.024.

26. Lui JK, Laws SM, Li QX, Villemagne VL, Ames D, Brown B, et al. Plasma amyloid-beta as a biomarker in Alzheimer's disease: AIBL study of aging. J Alzheimers Dis. 2010; 20(4):1233-42.

27. Cosentino SA, Stern Y, Sokolov E, Scarmeas N, Manly JJ, Tang MX, et al. Plasma $\beta$-amyloid and cognitive decline. Arch Neurol. 2010; 67(12):1485-90. DOI: 10.1001/archneurol.2010.189.

28. Laske C, Sopova K, Gkotsis C, Eschweiler GW, Straten $\mathrm{G}$, Gawaz M, et al. Amyloid- $\beta$ peptides in plasma and cognitive decline after 1 year follow-up in Alzheimer's disease patients. J Alzheimers Dis. 2010; 21(4):1263-9.

29. Yaffe K, Weston A, Graff-Radforf NR, Satterfield S, Simonsick EM, Younkin LH, et al. Association of plasma beta-amyloid level and cognitive reserve with subsequent cognitive decline. JAMA. 2011. 305(3):261-6. DOI: $10.1001 /$ jama.2010.1995.

30. Van Oijen M, Hofman A, Soares HD, Koudstaal PJ, Breteler MM. Plasma Abeta(1-40) and Abeta(1-42) and the risk of dementia: a prospective case-control study. Lancet Neurol. 2006 Aug; 5(8):655-60. DOI: 10.1016/ S1474-4422(06)70501-4.

31. Schupf N, Tang MX, Fukuyama H, Manly J, Andrews $\mathrm{H}$, Mehta P, et al. Peripheral Abeta subspecies as risk biomarkers of Alzheimer's disease. Proc Natl Acad Sci USA. 2008 Sep 16; 105(37):14052-7. DOI: 10.1073/ pnas.0805902105.

32. Wu G, Sankaranarayanan S, Wong J, Tugusheva K, Michener MS, Shi X, et al. Characterization of plasma $\beta$-secretase (BACE1) activity and soluble amyloid precursor proteins as potential biomarkers for Alzheimer's disease. J Neurosci Res. 2012 Dec; 90(12):2247-58. DOI: $10.1002 /$ jnr.23122.

33. Noguchi-Shinohara M, Hamaguchi T, Nozaki I, Sakai K Yamada M. Serum tau protein as a marker for the diagnosis of Creutzfeldt-Jackob disease. J Neurol. 2011 Aug; 258(8):1464-8. DOI: 10.1007/s00415-0115960-x.

34. Zetterberg H, Wilson D, Andreasson U, Minthon $\mathrm{L}$, Blennow K, Randall J, et al. Plasma tau levels in Alzheimer's disease. Alzheimers Res Ther. 2013; 5(2):9. DOI: 10.1186/alzrt163. 
35. Randall J, Mortberg E, Provuncher GK, Fournier DR, Duffy DC, Rubertsson S, et al. Tau proteins in serum predict neurological outcome after hypoxic brain injury from cardiac arrest: results of a pilot study. Resuscitation. 2013 Mar; 84(3):351-6. DOI: 10.1016/j. resuscitation.2012.07.027.

36. Liliang PC, Liang CL, Weng $\mathrm{HC}$, Lu K, Wang KW, Cheng HJ, et al. Tau proteins in serum predict outcome after severe traumatic brain injury. J Surg Res. 2010 May 15; 160(2):302-7. DOI: 10.1016/j.jss.2008.12.022.

37. Goetzl EJ, Boxer A, Schwartz JB, Abner EL, Petersen $\mathrm{RC}$, Miller BL, et al. Altered lysosomal proteins in neural-derived plasma exosomes in preclinical Alzheimer disease. Neurology. 2015 July 7; 85(1):40-47. DOI: 10.1212/WNL.0000000000001702.

38. Zarrouk A, Riedinger JM, Ahmed SH, Hammami S, Chaabane W, Debbabi M, et al. Fatty acid profiles in demented patients: identification of hexacosanoic Acid (c26:0) as a blood lipid biomarker of dementia. J Alzheimers Dis.2015; 44(4):1349-59.

39. Han X, Rozen S, Boyle SH, Hellegers C, Cheng H, Burke JR, et al. Metabolomics in early Alzheimer's disease: identification of altered plasma shpingolipidome using shotgun lipidomics. PLoS One. 2011; 6(7):e21643. DOI: 10.1371/journal.pone.0021643
40. Mielke MM, Haughey NJ, Bandaru VV, Weinberg DD, Darby E, Zaidi N, et al. Plasma sphiengomyelins are associated with cognitive progression in Alzheimer's disease. J Alzheimers Dis. 2011; 27(2):259-69.

41. Jerneren F. Brain atrophy in cognitively impaired elderly: the importance of long-chain omega-3 fatty acids and $\mathrm{B}$ vitamin status in a randomized controlled trial. Am J Clin Nutr. 2015. doi: 10.3945/ajcn.114.103283. DOI: $10.3945 /$ ajcn.114.103283.

42. Baierle M, Vencato PH, Oldenburg L, Bordingnon S, Zibetti M, Trentini CM, et al. Fatty acid status and its relationship to cognitive decline and homocysteine level in the elderly. Nutrients. 2014 Sep 12; 6(9):3624-40. DOI: $10.3390 /$ nu6093624.

43. Freund Levi Y, Vedin I, Cederholm T, Basun H, Faxen Irving $G$, Eriksdotter $M$, et al. Transfer of omega-e fatty acids across the blood-brain barrier after dietary supplementation with docosahexanoic acid-rich amega-3 fatty acid preparation in patients with Alzheimer's disease: the OmegAD study. J Intern Med. 2014 Apr; 275(4):428-36. DOI: $10.1111 /$ joim. 12166.

44. Mapstone M, Cheema AK, Fiandaca MS, Zhong X, Mhyre TR, MacArthur LH, et al. Plasma phospholipids identify antecedent memory impairment in older adults. Nat Med. 2014 Apr; 20(4):415-8. DOI: 10.1038/nm.3466. 